\title{
Diversity of diatom and carbon isotope characterization of soil organic matter in extreme climate, Sikkim Himalaya, India
}

\author{
Jyotsna Dubey ${ }^{1, *}$, Biswajeet Thakur ${ }^{1}$, Shailesh Agrawal $^{1}$, Anupam Sharma ${ }^{1}$, \\ P. Morthekai ${ }^{1}$, Vaibhava Srivastava ${ }^{2}$ and S. Nawaz Ali ${ }^{1, *}$ \\ ${ }^{1}$ Birbal Sahni Institute of Palaeosciences, Lucknow 226007 , India \\ ${ }^{2}$ Department of Geology, Faculty of Science, Banaras Hindu University, Varanasi 221005 , India
}

\begin{abstract}
Analysis of spatial variation of diatom assemblages and characterization of carbon isotopic composition of surface soil/sediment samples along three high-altitude transects (Chopta, Lashar and Gurudongmar valleys) in North Sikkim, Higher Himalaya have been done to delineate the ecological information (modern analogue). We have studied the variation in the distribution of diatom species and stable carbon composition in three different valleys having variable climatic conditions ranging from sub-humid to semi-arid. The results reveal that the biotic components respond appreciably towards varying environmental conditions. The spatial distribution of diatoms in surface sediments seems to be controlled by physical parameters such as temperature, water and nutrient availability. The overall $\delta^{13} \mathrm{C}$ values vary from $-25 \%$ to $-29 \%$, suggesting a $\mathrm{C}_{3}$-dominated vegetation in the region. Higher $\delta^{13} \mathrm{C}$ values are observed in Gurudongmar samples that are characterized by less moisture and low temperature. The $\delta^{13} \mathrm{C}$ values suggest that the source of organic matter in soil/sediment is contributed by open grasslands $\left(\mathrm{C}_{3}\right.$ grasses $)$. The isotope values clearly demonstrate an increase in $\delta^{13} \mathrm{C}$ values along with a progressive increase in elevation and decrease in precipitation. The present data will serve as an important archive for future correlations in palaeoclimatic studies.
\end{abstract}

Keywords: Carbon isotopes, diatom distribution, extreme climate, modern analogue, soil organic matter.

STABLE carbon isotope $\left(\delta^{13} \mathrm{C}\right)$ values and diatoms are among the most important proxies used for understanding the past climate dynamics ${ }^{1-5}$. However, like pollen, the understanding of modern isotopic composition and diatom distribution in the topsoil/sediments (modern analogue) from different climatic regimes of continental India and especially in the Higher Himalaya is lacking ${ }^{6}$. It is suggested that the climate exerts dominant control on spatial distribution of flora and fauna; hence the characterization of modern analogue is an essential step and

*For correspondence. (e-mail: jyotsnadubey91@gmail.com; snawazali@gmail.com) should be done in case of every proxy used for studies related to the past climate reconstruction ${ }^{7-10}$. The Higher Himalayan region with an elevation range of $~ 3000$ to more than $8000 \mathrm{~m}$ amsl experiences a transitional climate between the semi-arid (dry) northern Trans Himalayan region and sub-humid southern Himalayan region ${ }^{11,12}$. The flora and fauna of such sensitive zones respond to slight changes in climate variability and this is also recorded in the sedimentary archives ${ }^{13}$. In order to better understand the effects of climate change on both abiotic and biotic elements of different ecosystems, it is important to first understand the present-day dyna$\operatorname{mics}^{14-16}$

In view of the limited instrumental data records from the Himalayan region, the use of proxies is required to understand the present-day ecosystem dynamics and its response to past climatic variability. In high mountainous terrain, each proxy bears a limitation owing to the extreme climate and does not allow all modes of climate variability signatures to be captured. Therefore, different proxy records are studied simultaneously to infer the past climate. Biotic proxy indicators such as carbon isotope $\left(\delta^{13} \mathrm{C}\right)$ and diatoms are promising and direct indicators of climate as they respond to subtle changes in the environmental conditions owing to their high sensitivity to numerous environmental variables ${ }^{13,17-20}$. The carbon isotopic signatures of organic matter associated with soil/sediments (soil organic matter; SOM) have been widely used for understanding the vegetation types $\left(C_{3}\right.$, $\mathrm{C}_{4}$ and $\mathrm{CAM}$ ) and are an important tool to reconstruct the present and past climatic conditions of any region ${ }^{21}$. Similarly, most of the diatom species have a narrow tolerance towards site-specific characteristics, thus making them good indicators for palaeoecological reconstructions ${ }^{19,22-24}$. Their occurrence is also affected by altitudinal gradients, including climate, geology, topography, anthropogenic activities such as agriculture and use of water resources ${ }^{25}$.

The Higher Himalayan region ( $>4000 \mathrm{~m}$ amsl) is characterized by alpine vegetation dominated by grasses ${ }^{26,27}$. The grass family (Poaceae) is highly diversified in terms of photosynthesis, and both $\mathrm{C}_{3}$ and $\mathrm{C}_{4}$ species co-occur in 

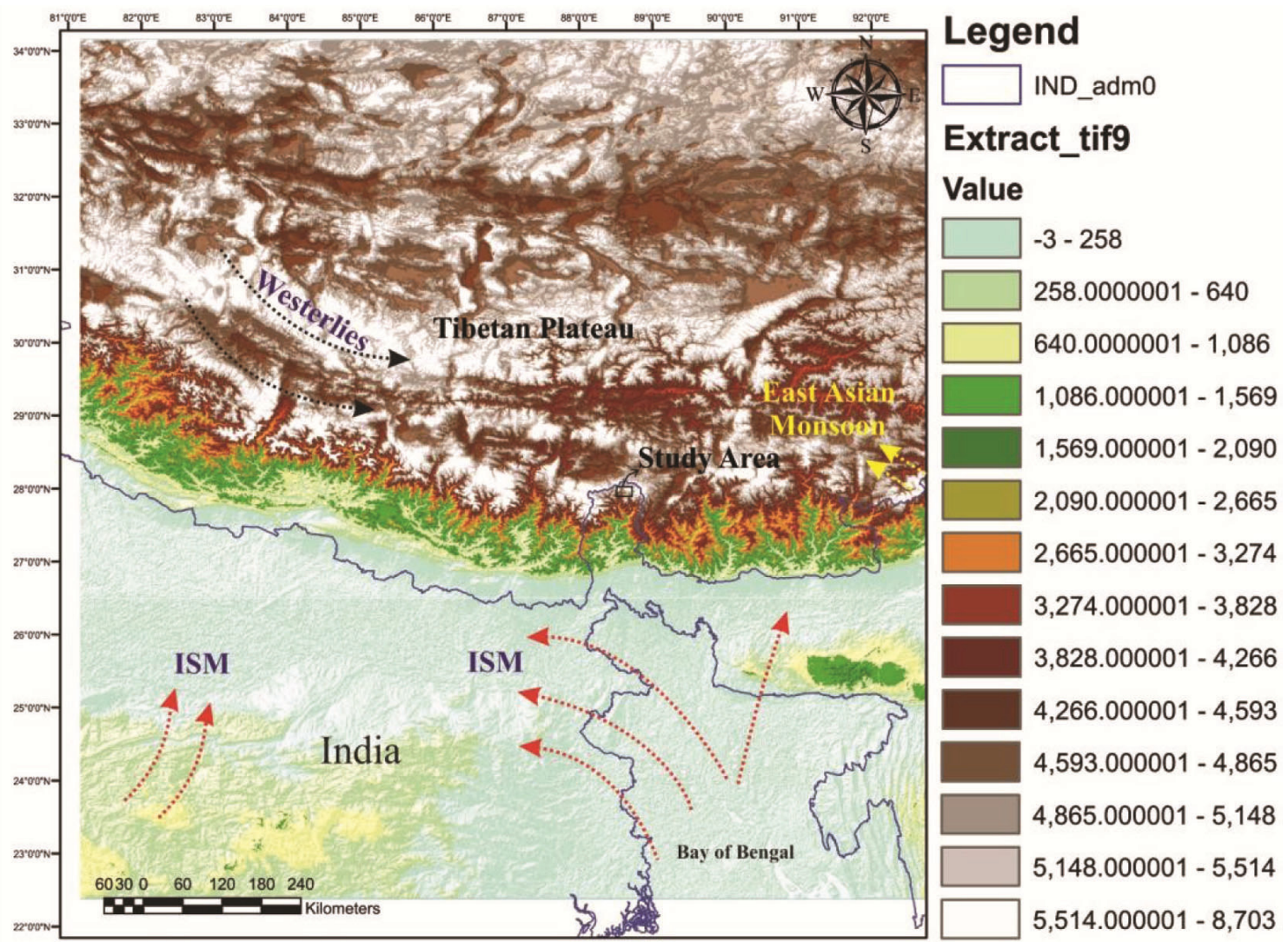

Figure 1. Shuttle radar topographic mission (SRTM) digital elevation model (DEM) showing the location of Sikkim (study area) and different weather systems, i.e. the Indian summer monsoon (ISM) and mid-latitude westerlies.

the tropical regions. In such cases, $\mathrm{C}_{3}$ grasses show clear tendency to dominate in relatively more humid as well as cooler areas. These ecological separations of $\mathrm{C}_{3}$ and $\mathrm{C}_{4}$ grasses have been seen across the latitudinal and altitudinal gradients in the tropical region, and gradient of water availability and seasonality ${ }^{21-28}$. Hence, the isotopic study is being increasingly used to understand photosynthetic pathway of plants as well as palaeovegetational/ climatic reconstruction.

In view of this, the present study delineates the diatom diversity in extreme climatic condition and characterizes the of $\delta{ }^{13} \mathrm{C}$ values of SOM in surface sediments from three different localities in the alpine zone of North Sikkim, Eastern Himalaya, India. The results will help to understand the relationship between modern conditions and the biotic analogues that will be useful in efficient interpretation of past $\delta^{13} \mathrm{C}$ and diatom assemblages for palaeoecological and palaeoclimatic reconstructions.

\section{Study area}

The study of modern stable carbon isotope composition of SOM and diatom assemblages was undertaken in North Sikkim, Higher Himalaya, India (Figure 1). Sikkim has a steep altitudinal gradient $(\sim 8300$ m elevation differ- ence over $100 \mathrm{~km}$ distance) resulting in complex topography that significantly controls the local weather patterns and gives rise to distinctive microclimatic niches

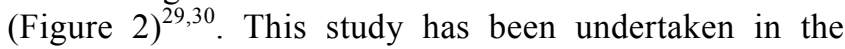
Chopta, Lashar and upper Tista (up to Gurudongmar lake) valleys $\left(27^{\circ} 03^{\prime} 41^{\prime \prime} \mathrm{N}\right.$ to $28^{\circ} 7^{\prime} 34^{\prime \prime} \mathrm{N}$ lat and $88^{\circ} 3^{\prime} 40^{\prime \prime} \mathrm{E}$ to $88^{\circ} 57^{\prime} 19^{\prime \prime} \mathrm{E}$ long) (Figure 2). Climatologically, the Chopta and Lashar valleys are located in the transitional zone of southern sub-humid Himalaya with characteristics of low to moderate vegetation and the northern semi-arid zone that includes Gurudongmar (Figure 3). The Chopta and Lashar valleys, lying at the boundary of the tree line, are broad, U-shaped, pro-glacial valleys. Geomorphologically, these valleys are occupied by glacial and glaciofluvial deposits like prominent moraines and outwash sediments. The Gurudongmar (lake) area is located at an altitude of $\sim 5150 \mathrm{~m}$ amsl in the upper catchment of Tista watershed. It is one of the largest moraine dammed glacial lakes in the Sikkim Himalaya covering an area of about $1.08 \mathrm{sq}$. km. The outlet of the lake is towards NNW direction and melt water of the lake is one of the sources of Chhombo River ${ }^{31}$. This area has scanty vegetation and experiences harsh semi-arid climate $^{32,33}$. The main plant species found in extreme cold regions of Sikkim (like Gurudongmar) are Elymus L. sp., Kobresia Willd. sp., Festuca L. sp., Poa L. 


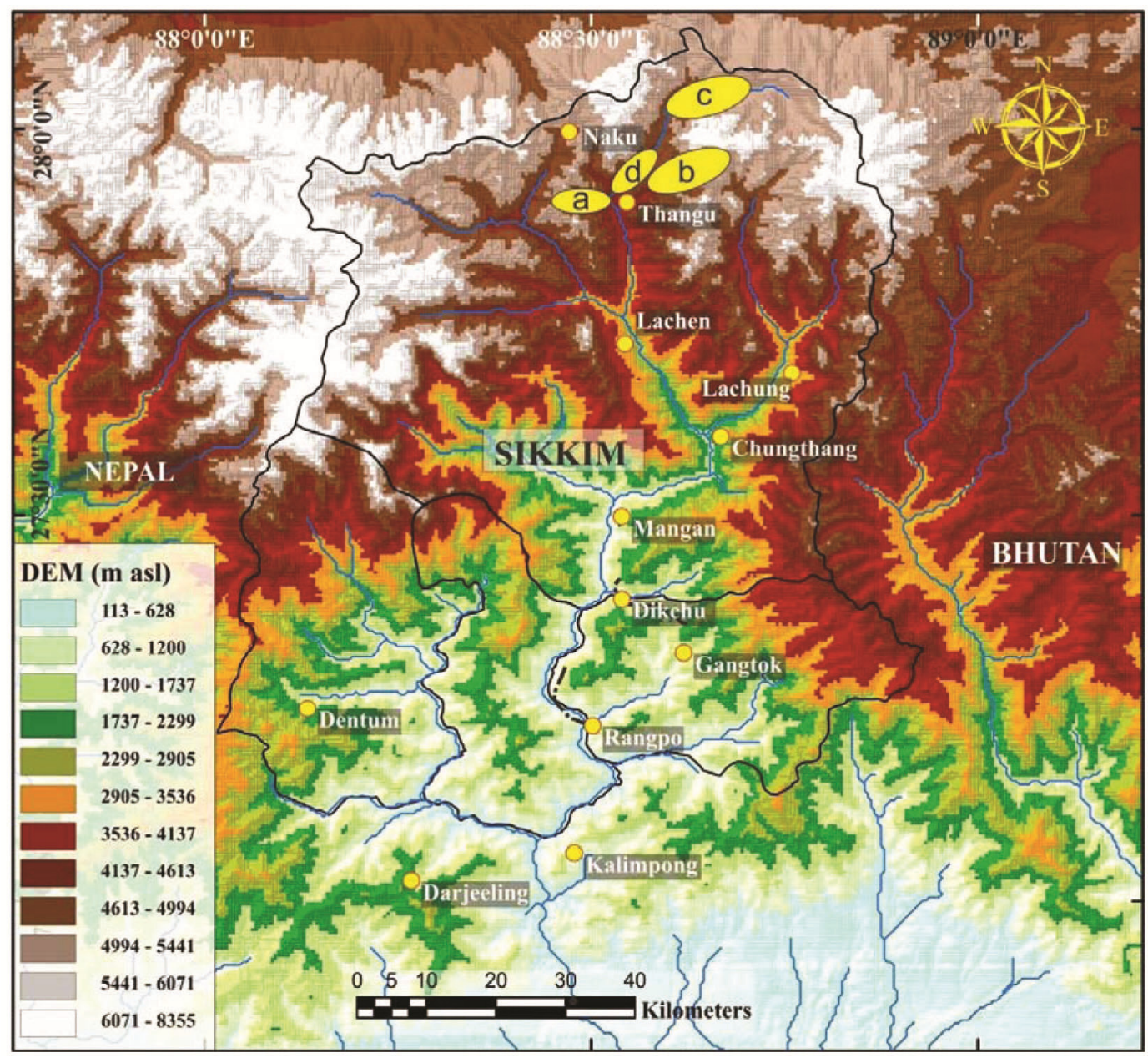

Figure 2. SRTM-DEM of Sikkim showing the state and district boundaries (black line), major drainages (blue lines), important towns/settlements (yellow dots) and sample locations sites (yellow ellipses) described in Figure 3.

sp., Acronema Falcon. ex Edgew., Aconitum L. spp., Gentiana L. sp., Primula L., Saxifraga L., Picrorhiza Royle Nardostachys grandiflora DC ${ }^{34}$ (CCS-Sikkim-2005). Being in the trajectory of the Bay of Bengal branch of the Indian summer monsoon (ISM), the Sikkim Himalaya experiences a humid climate in the southern parts, whereas towards the north (higher altitude) the ISM precipitation progressively decrease due to orographic effect ${ }^{1}$ and at the expanse of winter precipitation (snowfall) which is contributed by the southern branches of the mid-latitude westerlies $^{35-37}$.

\section{Vegetation}

Lashar and Chopta valleys situated at an elevation of $\sim 4000$ and $4500 \mathrm{~m}$ amsl respectively, mark the upper limit of the tree line and shelters alpine vegetation. Different high-altitude species like Primula L., Juniperus L., Rhododendrons L., Meconopsis Vig., Potentilla L. etc. are present in the study area ${ }^{31}$. Aconitum hookeri Stapf, Agrostis L. sp., Astragalus L. sp., Oxytropis DC. sp. etc. are other predominant species growing in this area. The area extending beyond Thangu (above $4000 \mathrm{~m}$ amsl) is the Himalayan rainshadow zone of cold desert that merges with Tibetan plateau. Above $\sim 4000 \mathrm{~m}$ amsl, the slopes are mildly undulating and the ground is mostly covered with scrubs like Rhododendron setosum D.Don, Rhododendron nivale Hook.f., Rhododendron anthopogon D.Don, Juniperus indica Bertol, Juniperus recurva Buch.-Ham. ex. D.Don, etc. The herb species prevalent in the area include Bergenia ligulata (Wall.) Engl., Corydalis DC. sp., Gaultheria L. sp., Gentiana L. sp., Ephedra L. sp., Arenaria L. sp., Lactuca L. sp., Taraxacum F.H.Wigg. sp., Saussurea DC. sp. and Aster L. sp. ${ }^{31}$.

\section{Methodology}

\section{Diatom sample preparation}

A total of 35 modern surface samples were collected from the high-altitude transitional zones of fairly vegetated Chopta-CHS (24 samples; BSIP museum sample 


\section{RESEARCH ARTICLES}
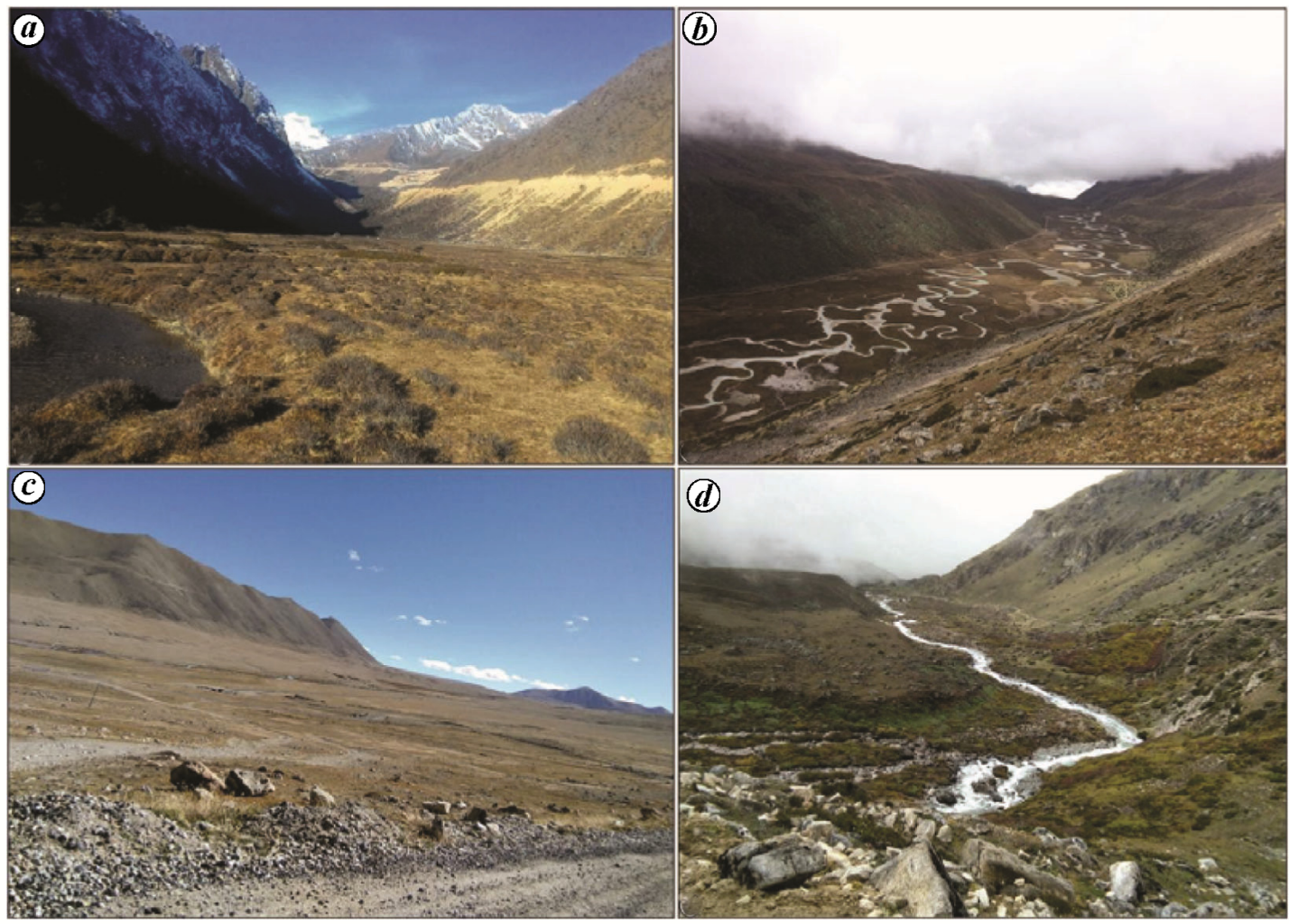

Figure 3. Field photographs. a, Facing the upstream direction showing the Chopta valley, North Sikkim, with alpine scrub vegetation demarcating the upper limit of the tree line. $\boldsymbol{b}$, Facing the downstream direction of the Lashar valley, showing relatively lesser vegetation. $\boldsymbol{c}$, Gurudongmar region with alpine barren condition. $\boldsymbol{d}$, Transition zone showing vegetation change from alpine scrub to alpine barren for the transect towards Gurudongmar.

accession no. 9051), Lashar-TVM (five samples; BSIP museum sample accession no. 9221) and semi-arid Gurudongmar-SK (six samples; BSIP museum sample accession no. 9221) valleys in North Sikkim during October 2017 to delineate the diatom diversity changes in extreme climatic regions (glacial environments). In order to extract diatoms, $\sim 2-3 \mathrm{~g}$ of dry sediment sample was treated with hydrochloric acid $(\mathrm{HCl})$ to dissolve and remove the carbonates. Subsequently, the samples were treated with $\mathrm{H}_{2} \mathrm{O}_{2}$ to remove organic matter. The samples were decanted and washed with distilled water to remove any acid used in the process. Four slides of each sample were prepared on a hot plate using mounting material ${ }^{38,39}$. The identification, classification and counting of diatoms were carried out following standard procedures ${ }^{40-42}$. For better representation, TILIA and TILIA graph software were used for the preparation of range chart and CONISS was applied for cluster analysis ${ }^{43}$ (Figure 4).

\section{Isotopic sample preparation}

The samples that were collected for diatom analysis were used for isotopic analysis as well. About $1 \mathrm{~g}$ of the sediment sample was taken after coning and quartering, and was finely powdered to clay size particles and poured into $50 \mathrm{ml}$ centrifuge tubes. The samples were treated with $5 \% \mathrm{HCl}$ solution (three times) for the removal of carbonates and washed with Milli-Q water using a centrifuge $(\sim 3000 \mathrm{r} / \mathrm{min})$ to remove acid and soluble salts. The decarbonated samples were then dried in a hot-air oven with temperature fixed at $45^{\circ} \mathrm{C}$. The oven-dried samples were again powdered with an agate mortar to loose clumps that might have formed during drying. All the acid-treated powdered samples were individually packed into tin capsules and introduced into the pre-filled and conditioned reactor of Elemental Analyser (Flash EA $2000 \mathrm{HT}$ ) through an autosampler. The $\mathrm{CO}_{2}$ gas produced through the combustion was introduced into the Continuous Flow Isotope Ratio Mass Spectrometer (CFIRMS, MAT 253) coupled with Con-Flow IV interface for isotopic analysis. The reproducibility of samples was checked by repeat measurements. References gas was calibrated using International Atomic Energy Agency (IAEA) $\mathrm{CH}-3$ and carbon isotopic data reported against Vienna Pee Dee Belemnite (VPDB). International standards (CH-3, and $\mathrm{CH}-6$ as well as sulphanilamide) were run to check the accuracy for $\mathrm{CO}_{2}$ measurements with an external precision of $0.1 \%$ ( $1 \sigma)$. All samples were analysed in the Stable Isotope Laboratory, Birbal Sahni Institute of Palaeosciences (BSIP), Lucknow. 
Table 1. Diatoms with abbreviations/codes used for statistical analysis

\begin{tabular}{|c|c|c|}
\hline Diatom genus & Codes used in statistical analysis & Diatom species \\
\hline Melosira & Mel & M. varians \\
\hline Cyclotella & Cyc & C. meneghiniana, C. striata \\
\hline Aulacoseria & Aul & A. granulata \\
\hline Pinnularia & Pin & P. borealis, $P$. gibba, $P$. virdis, $P$. biceps \\
\hline Eunotia & Eun & E. camelus, E. diodon, E. arcus, E. monodon \\
\hline Amphora & Amp & A. copulata \\
\hline Hantzschia & Han & H. amphioxys \\
\hline Nitzschia & Nit & N. clausii, N. palea \\
\hline Craticula & Cra & C. cuspidata \\
\hline Gomphonema & Gom & G. parvulum, G. gracile \\
\hline Neidium & Nei & Neidium sp. \\
\hline Achnanthidium & Ach & A. minutissimum \\
\hline Tabellaria & Tab & T. flocullosa \\
\hline Navicula & $\mathrm{Nav}$ & $N$. virdis, $N$. tenera, $N$. lancecolata \\
\hline Encyonema & Enc & E. hustedtii \\
\hline Caloneis & Cal & C. brevis \\
\hline Stauroneis & Sta & S. circumborealis, $S$. cf. kriegeri \\
\hline Achnanthes & Ach2 & A. brevipes \\
\hline Frustulia & Fru & F. saxonica \\
\hline Diatoma & Dia & D. vulgaris \\
\hline Cymbellonitzschia & Cym & Cymbellonitzschia sp. \\
\hline Cocconeis & $\mathrm{Coc}$ & C. placentula \\
\hline Sellaphora & Sel & S. pupula \\
\hline Fragillaria & Fra & $F$. rinoi $\mathrm{sp}$. \\
\hline Cymbella & Cym & C. aspera \\
\hline Anomoeneis & Ano & A. sphaerophora \\
\hline Surirella & Sur & S. gemma \\
\hline Diploneis & Dip & D. ovalis \\
\hline Hippodonta & Hip & H. capitata \\
\hline Epithemia & Epi & Epithemia sp. \\
\hline Bacillaria & $\mathrm{Bac}$ & B. paradoxa \\
\hline Gyrosigma & Gyr & G. acuminatum \\
\hline Synedra & Syn & S. $u \ln a$ \\
\hline Luticola & Lut & Luticola $\mathrm{sp}$. \\
\hline
\end{tabular}

\section{Numerical analyses}

PCA, redundancy analysis (RDA) and HCA were carried out to study variations and environmental drivers for these variations among the diatom species, and how the species are clustered respectively. We used detrended correspondence analysis (DCA) to choose whether linear or nonlinear (unimodal) ordination technique needs to be employed. Environmental gradient lengths using the different diatom genera (Table 1) were calculated from DCA and the DCA axis length score was found to be $2.3 \mathrm{SD}$. This indicates that environmental gradient is small (less than $3 \mathrm{SD}$ ) and suggests employing the linear model of ordination analysis, i.e. PCA to understand the variability among 34 genera and the factors that account for the variability. As altitude and $\delta^{13} \mathrm{C}(\%)$ values were available, both were used as explanatory variables. It is to be noted that although $\delta^{13} \mathrm{C}$ is not an explanatory variable in its strict sense, we used it as an indicator of water availability which is a driving force. However, these two explanatory variables are not the only controlling parameters for the variation in diatom genera, but other environmental factors also play a role.
Further, RDA, a constrained ordination analysis was used to know the relationship between altitude and $\delta^{13} \mathrm{C}$ to the biotic dataset. All the genera were used in the analyses with Hellinger transformation to reduce the impact of taxa with zero values ${ }^{44,45}$. All the analyses were done in R platform (R Core Team, 2014) using vegan package from CRAN project ${ }^{46}$.

\section{Results}

\section{Diatoms}

A total of 34 genera with three planktic and 31 benthic forms have been recorded in this study (Table 1 and Figure 4). It was observed that samples lying close to the river and moist places showed excellent diatom response both in assemblage and frequency; however, samples from the semi-arid zone did not yield rich assemblage $(<50$ cells). The major genera encountered in terms of frequency and abundance were Pinnularia, Eunotia, Amphora, Nitzschia, Hantzschia, Achnanthes, etc. (Figure 5). TILIA 1.7 and cluster analysis (CONISS) were used for 


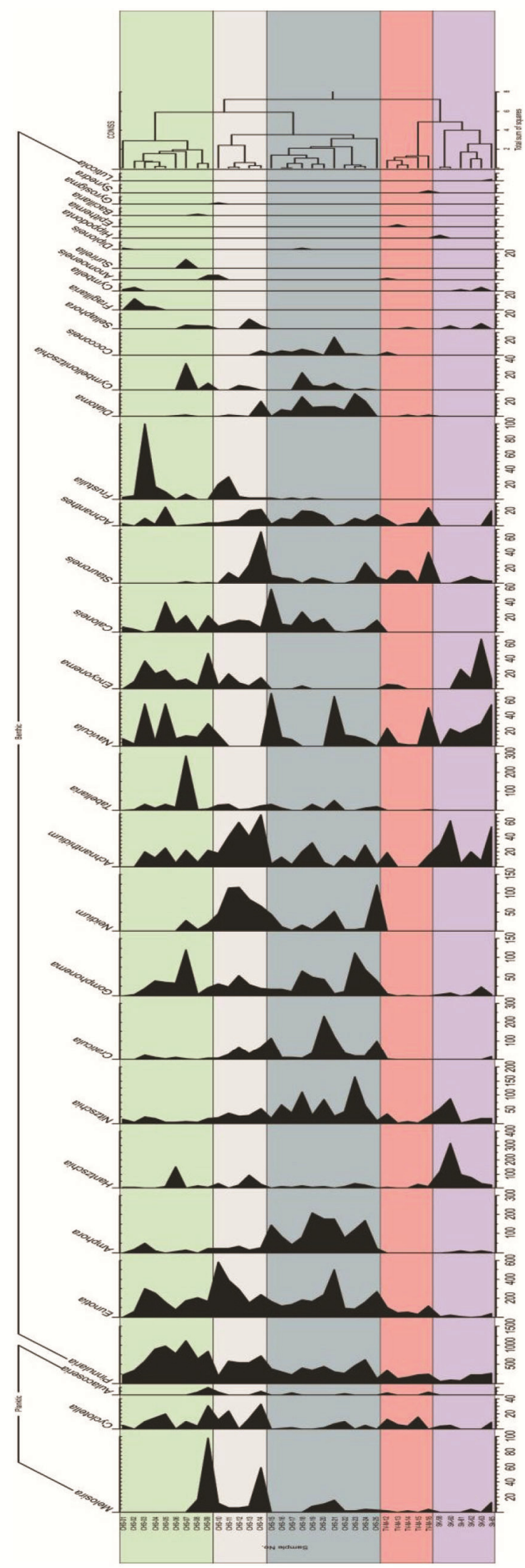

Figure 4. Frequency distribution of diatom genera in the surface samples from the Chopta, Lashar and Gurudongmar valleys with zonation based on cluster analysis. differentiating and grouping the diatom assemblage of the studied locations (Figure 4). The Tilia plot shows dominance of pennate (benthic) forms over the centric (planktic), and the ratio of centric to pinnate is very low $(<1)$. On the basis of cluster analysis, the assemblage has been broadly categorized into three major groups, i.e. Chopta (CHS), Lashar (TVM) and Gurudongmar (SK) and are described below.

Zone 1 -Gurudongmar (SK-65 to SK-58). This zone comprises samples collected in a transect along the Gurudongmar valley. Samples SK-58 to SK-60 were collected near the Gurudongmar lake and SK-61 to SK-63 were collected in the downstream area that represents the transitional zone, i.e. vegetated (grasses) to non-vegetated ( $\sim 90 \%$ barren) belt. Sample SK-65 has been collected further downstream ( $\sim 2 \mathrm{~km}$ upstream of Chopta) in a fairly vegetated (grasses) area. Among the benthic forms, Pinnularia is represented in the highest frequency ( 272) in samples SK 62, 63 and 65. Similarly, Hantzschia shows extremely high values $(\sim 315)$ in sample SK-60 and moderately high in sample SK-58 ( $\sim 120$ counts) lying close to the Gurudongmar lake outlet. Other benthic forms like Nitzschia and Achnanthidium are recorded in low frequency ranging from 4 to 88 counts, and Navicula, Encyonema, Eunotia, Gomphonema and Amphora are represented in low frequencies ( 4-54). The planktic forms such as Melosira and Cyclotella are sporadically represented.

Zone 2 - Lashar valley (TVM-12 to TVM-16). The samples collected from the Lashar valley yielded both benthic and planktic diatoms. Pinnularia shows the highest frequency with $\sim 162-345$ counts among all samples. Eunotia is recorded in fairly good frequency in samples TVM-16 ( 120) and TVM-12 ( 105), while it is scantily recorded in TVM-13 to TVM-15 ( $<60$ counts). In TVM16 , the diversity of few benthic diatoms like Navicula, Nitzschia, Achnanthes, Stauroneis and Hantzschia increases moderately, ranging from 15 to 50 counts. Other benthic diatoms like Encyonema, Craticula, Cocconeis, Tabellaria, Diatoma, Epithemia and Synedra are recorded in very low frequencies $(\sim 2-4)$. The planktic forms such as Cyclotella, Melosira and Aulacoseira are represented sporadically in this zone.

Zone 3 - Chopta valley (CHS-1 to CHS-25). The samples collected from the Chopta valley (marshy outwash plain) have yielded a rich diatom assemblage. On the basis of diatom frequency, this zone has been further categorized into three subzones $(3 a-3 c)$.

Zone 3 a (CHS-15 to CHS-25). This includes both benthic and planktic forms. The benthic form Pinnularia shows the highest frequency ( 623 , CHS-24) followed by Eunotia ( 90-503), Amphora ( 23-210), Craticula ( 9-229), 

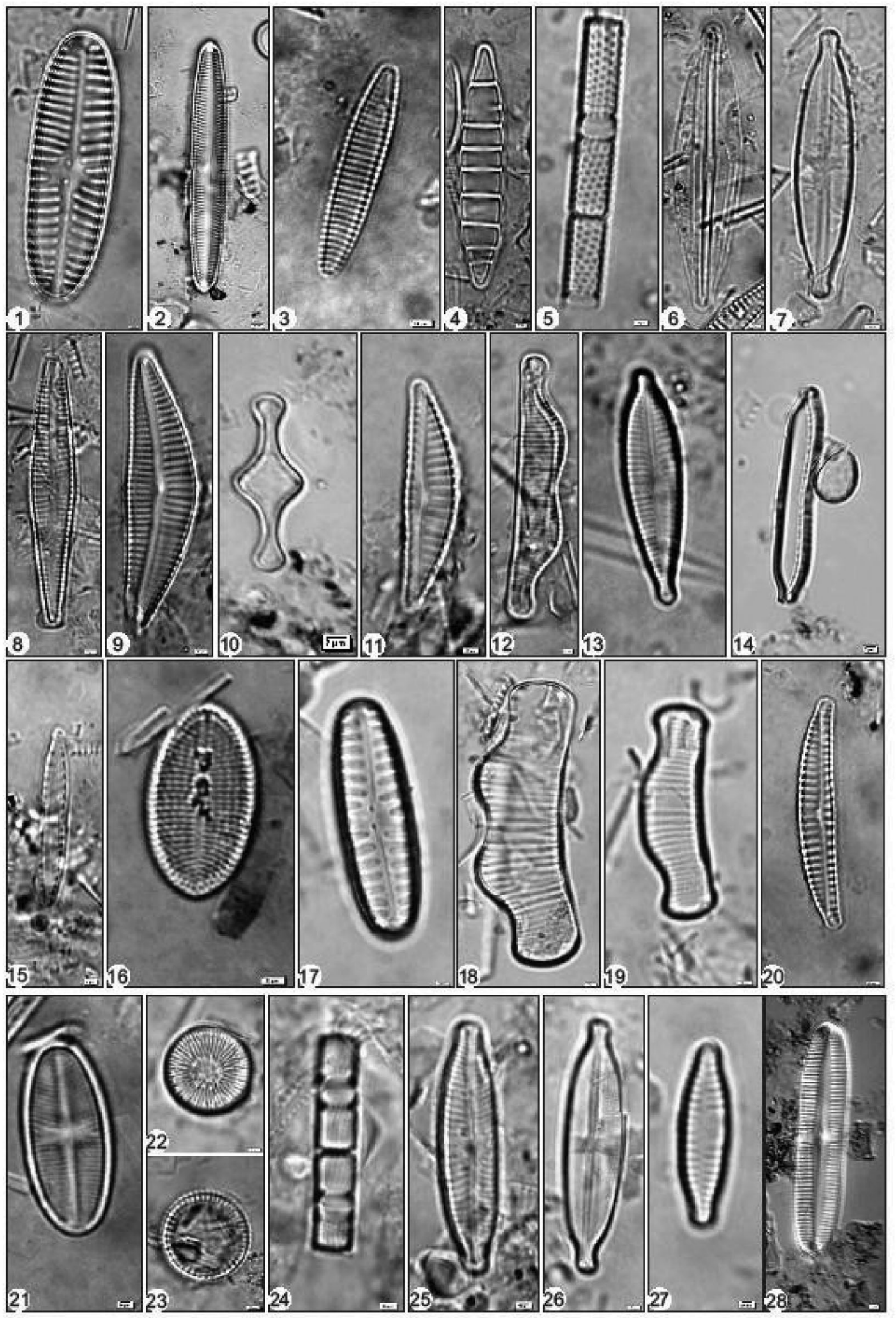

Figure 5. (1,17) Pinnularia borealis; (2) Pinnularia divergens; (3) Nitzschia amphibia; (4) Diatoma vulgaris; (5) Aulacoseira granulta; (6) Frustulia saxonica; $(7,26)$ Stauroneis circumborealis; (8) Gomphonema gracile; (9) Cymbella aspera; (10) Tabellaria flocculosa; (11) Encyonema hustedtii; (12) Eunotia diodon; (13) Gomphonema parvulum; (14) Hantzschia amphioxys; (15) Nitzschia clausii; (16) Cocconeis placentula; (17) Eunotia camelus; (18) Eunotia monodon; (19) Eunotia praerupta; (20) Amphora copulate; (21) Stauroneis cf. kriegeri; (22) Cyclotella striata; (23) Cyclotella meneghiniana; (24) Melosira varians; (25) Navicula lanceolata; (27) Fragilaria rinoi sp.; and (28) Pinnularia virdis. 
Nitzschia ( 10-165) and Gomphonema ( 5-113 counts). Navicula, Achnanthidium, Tabellaria, Caloneis, Hantzschia, Diatoma, Stauroneis, Cocconeis and Cymbellonitzschia are sporadically recorded ( 4-69). However, Encyonema and Diploneis are encountered only in sample CHS-18 in low frequencies $(\sim 2-4)$. The planktic diatoms Melosira, Cyclotella and Aulacoseira are sporadic.

Zone $3 b$ (CHS-10 to CHS-14). The benthic forms Pinnularia and Eunotia both show dissimilar behaviour and are recorded in low to high frequency ( 147-727). Neidium, Achnanthidium, Craticula, Nitzschia and Gomphonema also show significant values ( 157-429). However, Hantzschia, Nitzschia, Amphora, Stauroneis, Tabellaria, Achnanthes, Frustulia, Caloneis, Encyonema, Diatoma, Sellaphora, Navicula and Cymbellonitzschia show moderate to low counts. The planktic forms like Cyclotella and Melosira are occasionally present, but did not record more than 59 counts. In samples CHS-10 and CHS-15, the presence of Aulacoseira is recorded in extremely low counts $(\sim 4-5)$.

Zone 3c (CHS-1 to CHS-9). The samples CHS-1 to CHS9 record the highest frequency of Pinnularia ( 229-1119 counts) compared to all other zones, followed by Eunotia ( 60-350). The other benthic diatoms, namely Amphora, Hantzschia, Nitzshia, Craticula, Gomphonema, Neidium, Achnanthes, Tabellaria, Navicula, Encyonema, Caloneis, Frustulia and Achnanthidium show variable frequencies ranging from $\sim 2$ to 100 in most of the samples. The present range of diatoms also varies indifferently in many samples and may reflect environmental biases. The planktic form Melosira is recorded only among two samples with the highest frequency in sample CHS-9 ( 98) and lowest the frequency in CHS-8 ( 17). Similarly, Aulacoseira is also recorded only in two samples, viz. CHS-9 ( 10) and CHS-8 ( 4), whereas Cyclotella is sporadically recorded with variable frequency throughout this zone.

\section{$\delta^{13} C$}

The $\delta^{13} \mathrm{C}$ values of SOM in the Chopta valley range between $-25.8 \%$ and $-27.7 \%$ with an average of $-26.6 \%$. In case of the Lashar valley, almost similar values ranging between $-25.8 \%$ and $-27.3 \%$ with an average of $-26.5 \%$ have been recorded. On the other hand, the $\delta^{13} \mathrm{C}$ values of SOM in the Gurudongmar valley are relatively higher and range from $-24.9 \%$ to $-26.8 \%$ with an average of $-25.9 \%$.

\section{Ordination analysis}

PCA shows that first five components could only account for $52 \%(17.6 \%, 10.2 \%, 9.8 \%, 7.4 \%$ and $6.5 \%)$ of total variation in the genera data from different sample locations, as suggested by the scree plot (Figure 6, Table 1). RDA shows that a variation of $13.2 \%$ can only be constrained by $\delta^{13} \mathrm{C}$ and altitude, and the remaining variation $(86.8 \%)$ is left unconstrained. Both altitude (RDA 1$\left.69.9 \%, r^{2}=0.669\right)$ and $\delta^{13} \mathrm{C}$ (RDA $\left.2-30.1 \%, r^{2}=0.56\right)$ could explain $13.2 \%$ variability together in the diatom species data (Figure 7). Both the parameters are found to be significant with $P$-value $=0.001$. However, altitude was found to be significant than $\delta^{13} \mathrm{C}$ that is governing the variability in distribution of diatoms at different altitudes.

HCA was carried out to see how these samples at three different localities are clustered based on dissimilarities between the diatom genera using the observed characteristics. Figure $6 b$ and Figure $6 c$ show the results as a dendrogram and phylogram of unrooted type respectively. In Figure $6 d$, PCA and HCA results are shown together for comparison. We have observed that more than two clusters explain the data redundantly. All the analyses were carried out in R platform (R Core Team, 2014), and the CRAN packages used were vegan ${ }^{46}$ and ape ${ }^{47}$.

\section{Discussion}

Conventionally, modern analogues are used in palaeo(vegetation/climate) reconstructions to understand modern pollen-vegetation relationship in surface sediments. However, this approach is lacking in other proxy climate reconstruction studies from the Indian subcontinent. We propose that for every proxy reconstruction, understanding the present-day dynamics of the proxy and extant environmental condition is a pre-requisite. Towards this, we have made an effort to understand the distribution of diatoms and $\delta^{13} \mathrm{C}$ values along three climatologically different valleys (Chopta, Lashar and Gurudongmar) in North Sikkim, Higher Himalaya.

The diatom species reported in this study are dominated by pennate (benthic) forms, while the centric (planktic) forms are scanty. It has been observed that the samples collected near Gurudongmar show small diatom diversity. Diatom species like Hantzschia, Pinnularia and Nitzschia show dominance over centric forms, viz. Cyclotella and Melosira, indicating low water conditions in the region. The low turnout of Eunotia species also advocates for water scarcity. The total sum of diatoms dominated by benthic forms suggests nutrient availability owing to change in meltwater discharge during summer and winter seasons $^{25,37}$.

In the Lashar alpine valley, the diatom assemblage is dominated by Pinnularia followed by Eunotia, but with varying frequencies. Diatoms such as Navicula, Nitzschia, Achnanthes, Stauroneis and Hantzschia are recorded in low to moderate frequencies. The planktic forms such as Cyclotella, Melosira and Aulacoseira are sporadically 

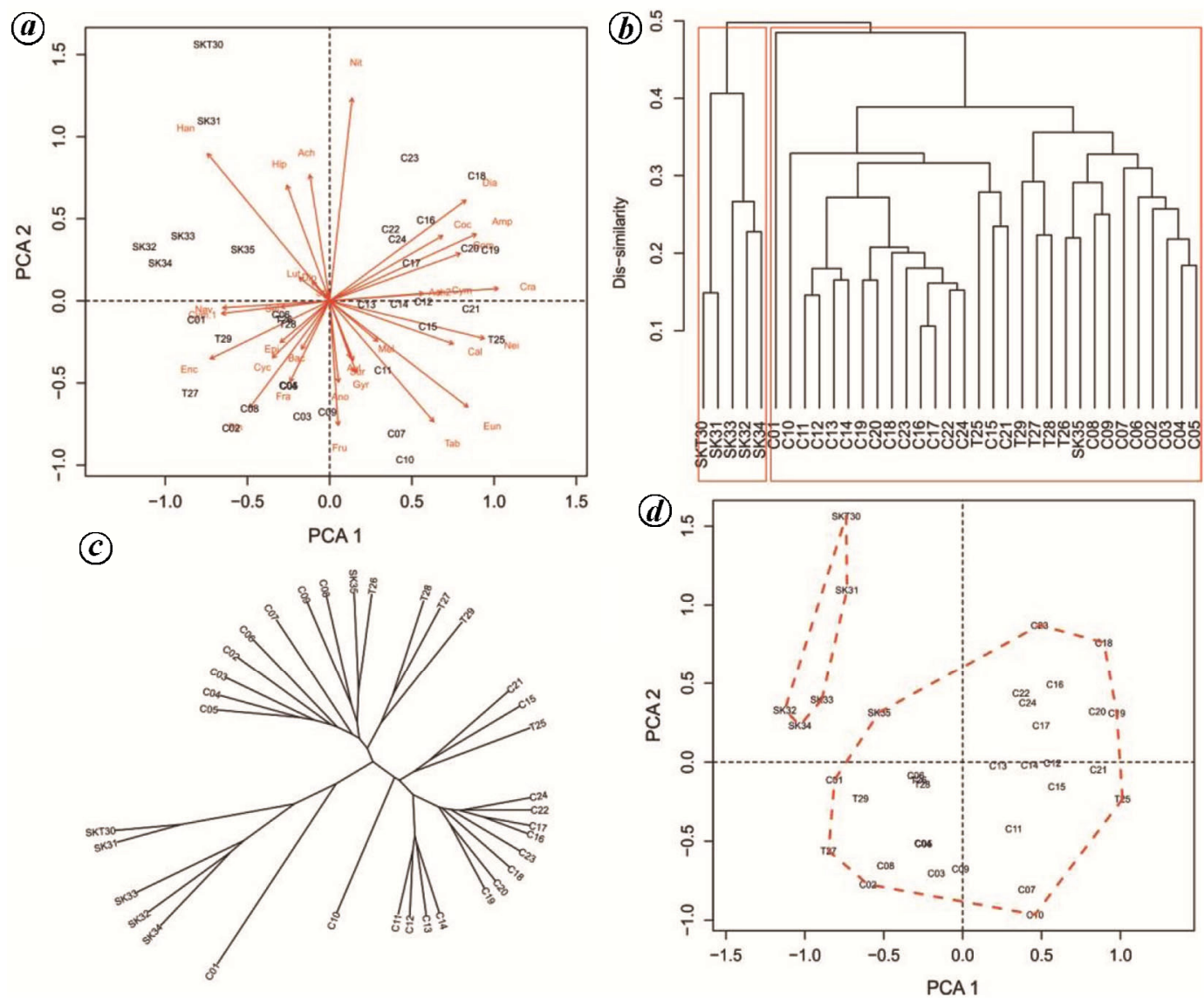

Figure 6. Statistical analysis. a, Biplot to visualize the principal component analysis (PCA) results. PCA was done based on the diatom genus of each sample. The diatom genera abbreviations/codes are given using the first three letters (Table 1). The red arrowed lines are the characteristics of the genera. $\boldsymbol{b}$, Dendrogram of the sample locations from the three alpine valleys (C, Chopta; T, Lashar: SK, Gurudongmar). $c$, Phylogram of the sample locations from the three alpine valleys based on the dissimilarity indices between the species using hierarchical cluster analysis (HCA). d, Combination of the results obtained from PCA and HCA. *Abbreviations/codes for diatom genera used in statistical analysis are given in Table 1.

represented in the assemblage. The overall representation suggests that the region experiences a cold wet environment with very low human activity ${ }^{48,49}$. Also, the depositional environment shows pristine water conditions with low to moderate nutrient availability. It is also observed that the diatom variation is subjected to available water conditions that may have resulted due to landscape variations $^{48}$.

The Chopta Valley (marshy outwash plain) shows a significant heterogeneity in diatom assemblage. Samples CHS-15 to CHS-24 (collected in the downstream part of the valley) are dominated by the benthic diatoms. This may be attributed to the close proximity of the melt water stream and high nutrient availability (marshy landscape). The planktic forms are represented in low counts, suggesting extremely shallow water depth. The high counts of Pinnularia, Eunotia, Amphora, Craticula, Nitzschia and Gomphonema further advocate for pelagic conditions prevailing in the valley under marshy conditions. The availability and diversity of Eunotia suggest pristine water conditions. Anthropogenic activity can be interpreted to some extent from Navicula, Achnanthidium, Tabellaria, Caloneis, Hantzschia, Diatoma, Stauroneis, Cocconeis and Cymbellonitzschia, and is in agreement with the field observations as this valley is being used as a pasture land by the locals ${ }^{25}$. In zone- 3 b comprising samples collected along the melt water stream (upstream part of the valley), a significant increase in Cyclotella and Melosira is observed, indicating enhanced melt water availability. The moderate rise in Achnanthidium, Nitzschia, Gomphonema, Tabellaria, Achnanthes, Frustulia and Cymbellonitzschia suggests increased human activity associated with grazing practices. The zone-3c samples were collected along the northern boundary (foothill) of the valley. This zone records the highest frequency of Pinnularia followed by Eunotia with varying frequencies of Amphora, Hantzschia, Nitzshia, Craticula, Gomphonema, Neidium, Achnanthes, Tabellaria, Navicula, Encyonema, Caloneis, Frustulia and Achnanthidium, suggesting a more drier depositional environment with 


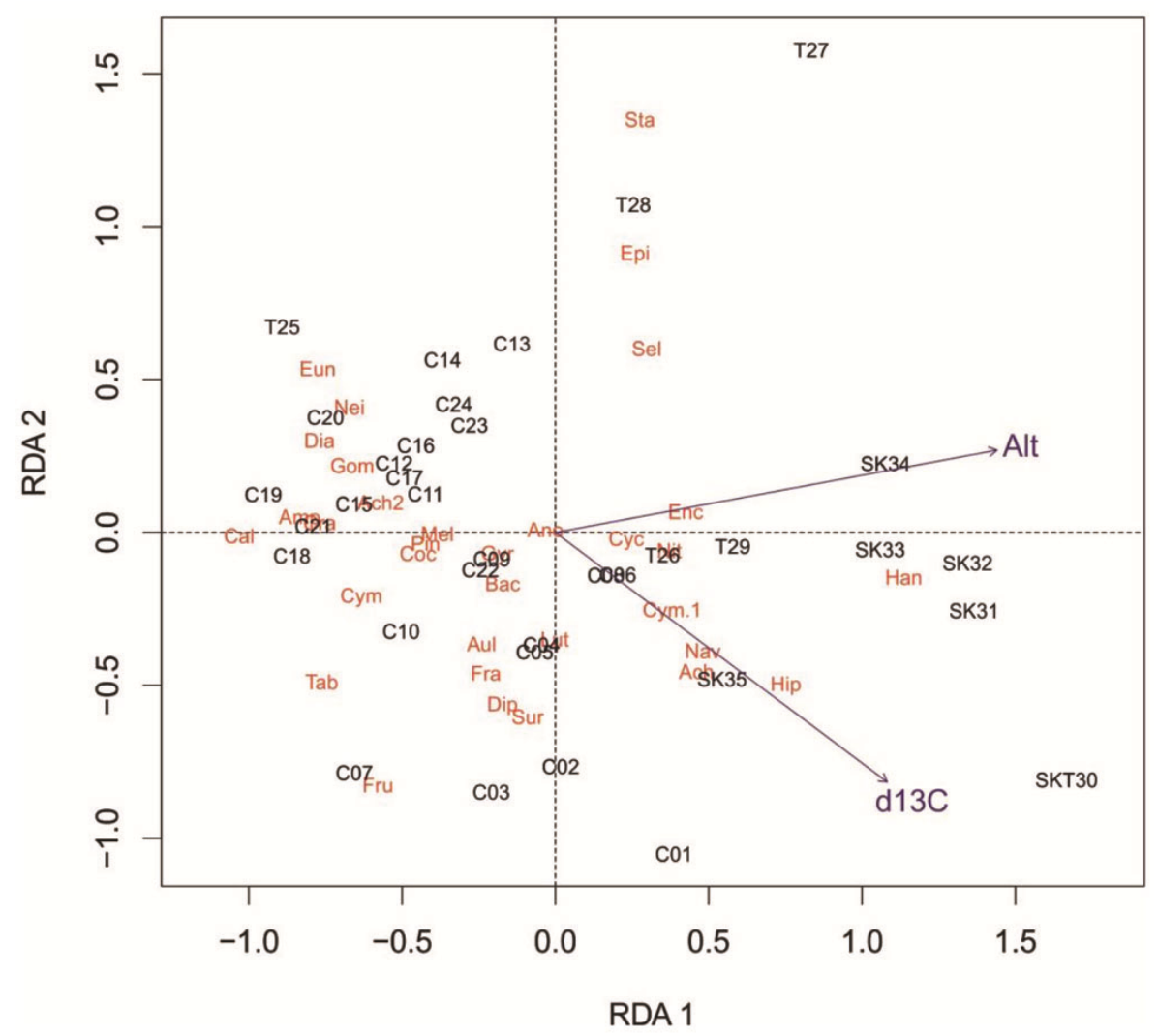

Figure 7. Redundancy analysis using diatoms as the response variable, and altitude and $\delta^{13} \mathrm{C}$ as explanatory variables. Numerics are the sample number $(C-n$, where $n$ varies from 1 to 24 for samples from Chopta valley, T-25 to 29 is for samples from Lashar valley and SK-30 to 35 for samples from Gurudongmar) and capital texts (first three letter of the genera) are the first three-letter code diatom genera.

fluctuating water levels. Melosira is recorded in higher frequency only in sample CHS-9, which may be attributed to moist environment. The results demonstrate the role of moisture availability in diatom diversity under microclimatic conditions. The diatom assemblage shows a significant contrast in different samples, suggesting a less diversified assemblage towards the hill slope as a result of sloping environments which may have allowed limited water availability for diatom growth ${ }^{25,48}$.

The study area is located at an altitude of $>4000 \mathrm{~m}$ amsl (alpine meadow) and is dominated by $\mathrm{C}_{3}$ vegetation. The carbon isotopic composition of modern $\mathrm{C}_{3}$ plants exhibits a wide range from $-20 \%$ o to $-36 \%$ (ref. 21 ). Such a large range in $\delta^{13} \mathrm{C}$ values can be explained by a physiological response to aridity (anomalously high $\delta^{13} \mathrm{C}$ ) as well as a low light levels plus leaf litter recycling (anomalously lower $\delta^{13} \mathrm{C}$ ). Considering the typical global average $\delta^{13} \mathrm{C}$ values (about $-26 \%$ o to $-27 \%$ ) of $\mathrm{C}_{3}$ plants, the $\delta^{13} \mathrm{C}$ values of SOM in these three Himalayan valleys suggest that sources of organic matter are from open grasslands at high altitudes consisting of $\mathrm{C}_{3}$ grasses.

The spatial distribution of $\delta^{13} \mathrm{C}$ values and the associated present-day environmental condition of the three valleys show a strong relationship between water availability and isotopic values. The isotopic values (SOM) of
Chopta and Lashar valleys that are located just above the present-day tree line and have a moderate annual precipitation $(\sim 1100 \mathrm{~mm} /$ year $)$ are fairly low $(-25.8 \%$ o and $-27.7 \%$, avg. $-26.6 \%$ o) ${ }^{13}$. However, the Gurudongmar valley samples show relatively higher values ranging between $-24.9 \%$ and $-26.8 \%$ with an average of $-25.9 \%$. As expected, the isotope values show low moisture availability and are in agreement with the semi-arid condition of Gurudongmar valley.

We have compared the average isotopic values (SOM) from the three valleys with the available regional as well as global carbon isotopic records. Modern isotopic analogues from the Indian subcontinent are lacking, except for a few from the Gangetic Plain ${ }^{28,50,51}$ and the Himalaya ${ }^{1}$. The $\delta^{13} \mathrm{C}$ values of modern $\mathrm{C}_{3}-\mathrm{C}_{4}$ plants from the different part of the Gangetic Plain have been analysed, and majority of $\delta^{13} \mathrm{C}$ values of $\mathrm{C}_{3}$ plants in different locations of the Ganga Plain vary from $-28 \%$ o to $-32 \%$ (refs 28,50 and 51). These lower values are in agreement with the $\delta^{13} \mathrm{C}$ values of the tropical region. In comparison to the tropical region, the $\delta^{13} \mathrm{C}$ values of $\mathrm{SOM}$ in the higher altitude of the Himalayan region are less negative. Higher $\delta^{13} \mathrm{C}$ values found in the present study are characteristic of the temperate regions and vary between $-25 \%$ and $-29 \%$. The difference in $\delta^{13} \mathrm{C}$ values between the 
Gangetic Plain and Higher Himalaya can be explained by a sharp decline in the moisture availability (ISM) along a south to north transect attributed to the Himalayan topography. Apart from moisture availability, lower temperature in the Himalayan region leads to lower ratios of stomatal conductance to photosynthesis by decreasing the $\mathrm{ci} / \mathrm{ca}$ ratio (ratio of partial pressure of $\mathrm{CO}_{2}$ inside the leaf to that of the atmosphere), and is implicated for higher $\delta^{13} \mathrm{C}$ values in these areas ${ }^{52}$. The present study demonstrated a sharp contrast in both diatom assemblages and $\delta^{13} \mathrm{C}$ values at microclimatic level. Hence, we propose that before taking up palaeoclimatic/environmental studies in different climatic regimes of the Higher Himalaya, understanding the response of different proxies to presentday climatic conditions (modern analogues) is essential, and this practice should be followed.

\section{Conclusion}

The present study gives some important insights on the diversity of diatoms in different environmental settings under extreme/harsh climatic conditions along with the characterization of $\delta^{13} \mathrm{C}$ values of SOM. The main conclusions drawn from this study are as follows:

- The diatom diversity shows a significant response to moisture availability within a single valley and hence suggests the role of microclimatic condition.

- Lower diatom diversity is a response to low water availability as observed in Gurudongmar samples and hill slope samples of Chopta valley.

- This $\delta^{13} \mathrm{C}$ values suggest that the source of organic matter in soil/sediments is contributed by open grasslands $\left(\mathrm{C}_{3}\right.$ grasses $)$.

- The higher $\delta^{13} \mathrm{C}$ values recorded in Gurudongmar samples advocate for moisture deficiency and lower temperatures.

- The present data provide a base for future palaeovegetation and palaeoclimate reconstruction from the region.

1. Cerling, T. E., The stable isotopic composition of modern soil carbonate and its relationship to climate. Earth Planet. Sci. Lett., 1984, 71, 229-240.

2. Schleser, G. H., Helle, G., Lücke, A. and Vos, H., Isotope signals as climate proxies: the role of transfer functions in the study of terrestrial archives. Quarter. Sci. Rev., 1999, 18(7), 927-943.

3. Mackay, A. W., Jones, V. J. and Battarbee, R. W., Approaches to Holocene climate reconstruction using diatom. In Global Change in the Holocene (eds Mackay, A. W. et al.), Arnold, London, UK, 2003, pp. 294-309.

4. Janbu, A. D., Paasche, Ø. and Talbot, M. R., Palaeoclimate changes inferred from stable isotope and magnetic properties of organic-rich lake sediments in Arctic Norway. J. Paleolimnol., 2011, 46(1), 29; doi.org/10.1007/s10933-011-9512-2.

5. Agrawal, S., Sanyal, P., Sarkar, A., Jaiswal, M. K. and Dutta, K., Variability of Indian monsoonal rainfall over the past $100 \mathrm{ka}$ and its implication for $\mathrm{C} 3-\mathrm{C} 4$ vegetational change. Quarter. Res., 2012, 77, 159-170.

6. Dubey, J., Ghosh, R., Agrawal, S., Quamar, M. F., Morthekai, P., Sharma, R. K., Sharma, A., Pandey, P. and Ali, S. N., Characteristics of modern biotic data and their relationship to vegetation of the Alpine zone of Chopta valley, North Sikkim, India: implications for palaeovegetation reconstruction. The Holocene, 2018, 28, 363-376.

7. Birks, H. J. B. and Birks, H. H., Quaternary Palaeoecology, Edward Arnold, London, 1980, p. 289.

8. Sharma, K. K., Geologic and tectonic evolution of the Himalaya before and after the India-Asia collision. Proc. Indian Acad. Sci. Earth Planet. Sci., 1998, 107(4), 265-282.

9. Ahmad, T., Geology of the Himalayan Mountain Range, with special reference to the western Himalaya. Geologi, 2011, 63, 142 147.

10. Gaillard, M. J., Birks, H. J. B., Emanuelsson, U. and Berglund, B. E., Modern pollen/land-use relationships as an aid in the reconstruction of past land-uses and cultural landscapes: an example from south Sweden. Veget. Hist. Archaeobot., 1992, 1, 3-17.

11. Gosling, W. D., Mayle, F. E., Tate, N. J. and Killeen, T. J., Modern pollen-rain characteristics of tall terra firm moist evergreen forest, southern Amazonia. Quaternary Res., 2005, 64, 284-297.

12. Jackson, S. T. and Williams, J. W., Modern analogs in Quaternary paleoecology: Here today, gone yesterday, gone tomorrow? Ann. Rev. Earth Planet. Sci., 2004, 32, 495-537.

13. Ali, S. N. et al., High frequency abrupt shifts in the Indian summer monsoon since Younger dry as in the Himalaya. Sci. Rep., 2018, 8, 9287.

14. Falkowski, P. G., Fenchel, T. and Delong, E. F., The microbial engines that drive earth's biogeochemical cycles. Science, 2008, 320, 1034-1039.

15. Dawson, T. P., Jackson, S. T., House, J. I., Prentice, I. C. and Mace, G. M., Beyond predictions: biodiversity conservation in a changing climate. Science, 2011, 332, 53-58.

16. Convey, P. et al., The impacts of climate change on circumpolar biodiversity. Biodiversity, 2012, 13, 134-143.

17. Stoermer, E. F. and Smol, J. F., The Diatoms. Applications for the Environmental and Earth Sciences, Koeltz Scientific Books, Königstein, 1999.

18. Battarbee, R. W., Jones, V. J., Flower, R. J., Cameron, N. G., Bennion, H., Carvalho, L. and Juggens, S., Diatoms. In Tracking Environmental Change using Lake Sediments, Volume 3, Terrestrial, Algal, and Siliceous Indicators (eds Smol, J. P., Birks, H. J. B. and Last, W. M.), Kluwer Academic Publishers, Dordrecht, 2001, pp. 155-202.

19. Smol, J. P. and Stoermer, E. F. (eds), The Diatoms: Applications for the Environmental and Earth Sciences, Cambridge University Press, 2010, 2nd edn.

20. Michelutti, N., McCleary, K., Douglas, M. S. V. and Smol, J. P., Comparison of freshwater diatom assemblages from a High Arctic oasis to nearby polar desert sites and their application to environmental inference models. J. Phycol., 2013, 49, 41-53.

21. Kohn, M. J., Carbon isotope compositions of terrestrial C3 plants as indicators of (paleo)ecology and (paleo)climate. Proc. Natl. Acad. Sci. USA, 2010, 107, 19691-19695.

22. Prygiel, J., Whitton, B. A. and Bukowska, J., Review of the major diatom-based techniques for the quality assessment of rivers state-of-the-art in Europe. Artois Picardie, 1999.

23. Jiang, H., Siedenkrantz M. S., Knudsen, K. L. and Eiríksson, J., Diatom surface sediment assemblages around Iceland and their relationship to oceanic environmental variables. Mar. Micropal., 2001, 41, 73-96.

24. Hassan, G. S., Espinosa, M. A. and Isla, F. I., Modern diatom assemblages in surface sediments from estuarine systems in the southeastern Buenos Aires Province, Argentina. J. Paleolimnol., $2006,35,39$. 
25. Jüttner, I., Cox, E. J. and Ormerod, S. J., New or poorly known diatoms from Himalayan streams. Diatom Res., 2000, 15, $237-$ 262.

26. Champion, H. G. and Seth, S. K., A Revised Survey of the Forest Types of India, Government of India Press, Delhi, 1968, p. 404.

27. Tambe, S. and Rawat, G. S., The Alpine Vegetation of the Khangchendzonga Landscape, Sikkim Himalaya. Mountain Res. Dev., 2010, 30(3), 266-275.

28. Basu, S., Agrawal, S., Sanyal, P., Mahato, P., Kumar, S. and Sarkar, A., C isotopic ratios of modern C3-C4 plants from the Gangetic plain, India and its implications to paleovegetational reconstruction. Palaeogeogr., Palaeoclimatol., Palaeoecol., 2015, 440, 22-32.

29. Chettri, N., Sharma, E. and Deb, D. C., Bird community structure along a trekking corridor of Sikkim Himalaya: a conservation perspective. Biol. Conserv., 2001, 102, 1-16.

30. Basu, S. K., Geology of Sikkim State and Darjeeling District of West Bengal, Geological Society of India, Bangalore, 2013, p. 225

31. Anon., Environmental Information System (ENVIS) Centre, Ministry of Environment and Forest, Govt of India; http://www.sikenvis. nic.in/database/naturalresources 790.aspx?format=print

32. Das, D. and Keshri. J. P., Algae from Gurudongmar Lake (North Sikkim, Eastern Himalaya). NeBIO - Int. J. Environ. Biodivers., 2013, 4(6), 61-69.

33. Dubey, J. et al., Glacial geomorphology and landscape evolution of the Thangu Valley, North Sikkim Himalaya, India. J. Indian Soc. Remote Sensing, 2019, 47(5), 821-837.

34. Tamang, J. P., Thapa, M. P., Sharma, R. M., Rai, A. K., Rai, P. and Dhakal, R., Carrying capacity study of Teesta Basin in Sikkim. Environ. Infor. Syst. (ENVIS) Centre, Sikkim, 2005, p. 263.

35. Wei, K. and Gasse, F., Oxygen isotopes in lacustrine carbonates of West China revisited: implications for post glacial changes in summer monsoon circulation. Quat. Sci. Rev., 1999, 18, 13151334.

36. Yihui, D. and Zunya, W., A study of rainy seasons in China Meteorol. Atmos. Phys., 2008, 100, 121-138.

37. Ali, S. N., Dubey, J., Morthekai, P., Sharma, A., Singh, R. and Prizomwala, S., Climate forcing and the initiation of glacier advance during MIS-2 in the North Sikkim Himalaya, India. J. Asian Earth Sci., https://doi.org/10.1016/j.jseaes.2019.02.005

38. Battarbee, R. W. and Kneen, M. J., The use of electronically counted microspheres in absolute diatom analysis. Limnol. Oceanogr., 1982, 27, 184-188.

39. Battarbee, R. W., Diatom analysis. In Handbook of Holocene Palaeoecology and Palaeohydrology (ed. Berglund, B. E.), Wiley and Sons, New York, 1986, pp. 527-570.

40. Round F. E., Crawford, R. M. and Mann, D. G., The Diatoms. Biology and Morphology of the Genera, Cambridge University Press, 1990.

41. Jacob, J., Diatoms in the Swan River Estuary, Western Australia: Taxonomy and Ecology, Koeltz Scientific Books, 2012, p. 456.
42. Karthick, B., Hamilton, P. B. and Kociolek, J. P., An Illustrated Guide to Common Diatoms of Peninsular India, Gubbilabs, 2013, p. 206.

43. Grimm, E. C., TILIA and TILIA.GRAPH, PC spreadsheet and graphics software for pollen data. In: INQUA, Working Group on Data-handling Methods Newsletter, 1990, 4, 5-7.

44. Legendre, P. and Gallagher, E. D., Ecologically meaningful transformations for ordination of species data. Oceaologi, 2001, 129, 271-280.

45. Poos, M. S. and Jackson, D. A., Addressing the removal of rare species in multivariate bioassessments: the impact of methodological choices. Ecol. Indicator., 2012, 18, 82-90.

46. Oksanen, J. et al., Vegan: Community Ecology Package ( $R$ package version 2.2-1), 2015; http://CRAN.R-project.org/package=vegan

47. Paradis, E., Claude, J. and Strimmer, K., APE: Analyses of phylogenetics and evolution in R language. Bioinformatics, 2004, 20, 289-290.

48. Cantonati, M., Corradini, G., Jüttner, I. and Cox, E. J., Diatom assemblages in high mountain streams of the Alps and the Himalaya - Nova Hedwigia, Beih, 2001, 123, pp. 37-61.

49. Smol, J. P., Prolonged ice cover dampens diatom community responses to recent climatic change in high arctic lakes. Pollution of Lakes and Rivers, Blackwell Publishing, 2008, p. 392.

50. Agrawal, S., Srivastava, P., Meena, N. K., Rai, S. K., Bhushan, R., Misra, D. K. and Gupta, A. K., Stable $\left(\delta^{13} \mathrm{C}\right.$ and $\left.\delta^{15} \mathrm{~N}\right)$ isotopes and magnetic susceptibility record of late Holocene climate change from a lake profile of the northeast Himalaya. J. Geol. Soc. India, 2015, 86, 696-705.

51. Basu, S., Ghosh, S. and Sanyal, P., Spatial heterogeneity in the relationship between precipitation and carbon isotopic discrimination of C3 plants: Inferences from a global compilation. Global Planet. Change, 2019, 176, 123-131.

52. Farquhar, G. D., Ehleringer, J. R. and Hubick, K. T., Carbon isotope discrimination and photosynthesis. Annu. Rev. Plant Physiol. Plant Mol. Biol., 1989, 40, 503-537.

ACKNOWLEDGEMENTS. We thank the Director, Birbal Sahni Institute of Palaeosciences, Lucknow for support and providing infrastructure facilities. We also thank the Government of Sikkim for providing the necessary permissions and the staff for their help during the field work, and the Department of Science and Technology, Government of India for providing funds (SB/DGH-89/2014) to carry out the present study. J.D. also thanks the Council of Scientific and Industrial Research (CSIR) for financial support in the form of senior research fellowship.

Received 5 August 2019; revised accepted 21 April 2020

doi: $10.18520 / \mathrm{cs} / \mathrm{v} 119 / \mathrm{i} 4 / 649-660$ 